\title{
A MORAL E A POLÍTICA SOB A ÉGIDE DA NATUREZA OU NOS ANTÍPODAS DO UNIVERSAL ${ }^{*}$
}

\author{
Rita Paiva \\ Universidade Federal de São Paulo
}

\begin{abstract}
Resumo: Esse artigo visa problematizar a constituição da moral e da política, tal como fundamentadas por H. Bergson em sua última obra. Trata-se de compreender que essas dimensões da vida humana, ao menos enquanto tendências, mergulham suas raizes na natureza, o que eleva o propósito de conservação da espécie à condição de fim último da existir. Procura-se, assim, interrogar se com a atualização das virtualidades naturais que conformam a presença do homem no mundo, tanto a conduta moral quanto as ações políticas não findam por antagonizar com certos ideais instaurados no limiar da modernidade - e que, sob certas perspectivas, vicejam ainda no imaginário contemporâneo -, a saber: a expectativa de um progresso civilizatório pautado pela emancipação universal e pelo refluxo da violência.
\end{abstract}

Palavras-chaves: Progresso; Moral; Política; Natureza; Universalidade.

Abstract: This paper seeks to problematize the way in which moral and politics are constituted, as substantiated by $\mathrm{H}$. Bergson in his last work: 'The two sources of morality and religion.'. The aim is to understand that these two dimensions of human life, at least while considered as current trends, have their roots deep within our nature, and this is something which elevates the purpose of species conservation to the condition of ultimate goal of our existence. This way, the objective of this paper is to question if, even with the modernisation of the natural virtualities which make up the presence of mankind in the world, neither morality conduct nor political actions end up acting in opposition to some of the ideals that are now established on the thresholds of modernity - which also, under certain perspectives, still flourish within the contemporary imaginarium - knowingly: the expectation of some kind of civilising progress paced by universal emancipation and a backward flowing of violence.

Keywords: Progress; Moral; Politics, Nature; Universality.

Nossa contemporaneidade é herdeira claudicante das representações modernas. O crescente processo de racionalização do qual derivariam a

\footnotetext{
* Uma primeira versão dessa discussão foi apresentada oralmente no seminário A Sociedade da Indiferenciação; identidades, traumas e violência mítica, realizado no Instituto de Estudos Avançados da Universidade de São Paulo, em 24.02.2016.

(C) Dissertatio - Volume Suplementar 4, Dezembro - 2016
} 
ampliação dos horizontes cognitivos e da ciência, o irreversível avanço técnico com o consequente alargamento da produção de riquezas, a melhoria generalizada das condições materiais de existência associados à imagem de um homem e de uma sociedade universamente autônomos constituía o mote dessa era. Subjacente a essas representações, estava a aposta no refluxo da violência e da selvageria, na instauração futura da paz, talvez perpétua, como aquela postulada por Kant em alguns de seus textos, nos quais a força de uma razão universal se sobreporia ao poder e à incontestável insociabilidade dos homens. Estaria assim deflagrado, num percurso aparentemente irreversível, o progresso civilizacional e emancipatório.

O naufrágio das diretrizes centrais desse ideário foi há muito constatado. Algo dele subsiste? O progresso tecnológico e científico está aí para quem quiser ver; manco, sem dúvida, já que, a despeito de suas benesses, que são muitas, não traz consigo a vertente outra desses investimentos. Numa palavra, se esse projeto não se consumou sob a constelação entrevista pelo sonho iluminista - associado a uma representação de futuro pautada pelo aperfeiçoamento moral, pela libertação e pela paz universal -, poderíamos sustentar que ele se perpetua sob uma constelação outra, cujo tom é o do desencanto.

São, com efeito, inesgotáveis as searas filosóficas em que a ruína desse ideário foi problematizada. Nas páginas que se seguem, ela será abordada de forma bastante oblíqua, uma vez que nosso intuito consiste em acompanhar as reflexões presentes no último livro de $\mathrm{H}$. Bergson, no momento em que o filósofo da duração aborda a presença da natureza em nós enquanto pressuposto para que se viabilize a constituição da sociedade, da moral e da política. E faremos isso tomando como referência a crença nesse inexorável progresso civilizatório. Destarte, ao incursionarmos por algumas das análises tecidas em As duas fontes da moral e da religião, será possível entrevermos o modo inusitado pelo qual o pensamento bergsoniano, sem que se renda ao entusiasmo iluminista, atualiza as questões e os ideais instaurados no limiar modernidade, particularmente aqueles ligados à representação de uma emancipação universal e do aperfeiçoamento moral.

Iniciemos com uma alusão a algumas passagens pertinentes à conferência intitulada $A$ consciência e a vida e à Evolução Criadora. No processo de evolução a liberdade imanente ao processo vital, não sem um imenso esforço, insere-se na matéria, sucumbindo ou cessando seu avanço em vertentes várias, salvo aquela que leva ao homem. Lemos na conferência publicada em 1919:

Em resumo, é como se uma imensa corrente de consciência, na qual se interpenetrassem virtualidades de todo tipo, tivesse atravessado a matéria para impulsioná-la rumo à organização e para torná-la, embora ela seja a própria 
necessidade, um instrumento de liberdade. Mas a consciência quase foi apanhada na armadilha. A matéria enrola-se em torno dela em sua própria inconsciência. Em certas linhas da evolução, particularmente as do mundo vegetal, automatismo e inconsciência são a norma; é bem verdade que a liberdade imanente à força evolutiva ainda se manifesta pela criação de formas imprevisíveis que são autênticas obras de arte; mas essas formas imprevisíveis, uma vez criadas, vão se repetindo maquinalmente; o indivíduo não escolhe. (...) da base ao topo da escala da vida, a liberdade está presa a uma corrente que ela, quando muito, consegue alongar. Somente com o homem é dado um salto brusco; a corrente rompe-se (BERGSON, 2009b, p.19).

Assim, a vida, com a sua obra maior, já não sucumbe às estagnações e ao automatismo, mas supera os obstáculos que até então a paralisavam, obstando a irrupção da consciência em sua mais larga amplitude. Com o aparecimento do homem, já não se configura a urgência de que o impulso movente em seu embate com a materialidade contorne as formas vivas cristalizadas pelas rotinas e pelo automatismo; torna-se prescindível o esforço para a instauração de uma espécie outra, dotada de maior complexidade. É pela abertura intrínseca à inteligência humana, que o brinda com a capacidade indeterminada de fabricação, invenção e superação de seus limites que o ser humano perpetua o movimento da vida. Graças ao seu cérebro, à sociedade, à linguagem a ele caberá o privilégio de inserir 'novidade no mundo' e de superar os obstáculos, talvez mesmo a morte da espécie. $\mathrm{O}$ autor em $A$ evolução criadora:

Por toda outra parte que não no homem, a consciência viu-se acuada contra um beco sem saída; apenas com o homem ela prosseguiu seu caminho. O homem continua portanto indefinidamente o movimento do elã vital, ainda que não arraste consigo que a vida carregava em si (...) (Bergson, 2005, p. 287).

Só o homem salta do fechado ao aberto estabelecendo o abismo entre a sua condição e todas as outras espécies. É este ser criador o maior sucesso vital.

Daí deriva que uma vez realizada a sua investigação acerca da história da vida, o autor volte seu olhar para a cultura. A inspeção acerca do processo em que a vida perpetua sua propensão criadora - através da história e das obras humanas - torna imperativa a problematização da natureza da própria sociedade e de seus desdobramentos, tais como a moral e a política. As perspectivas que o autor vislumbrará nessa trilha, em que já não se limita a contrapor a espécie humana às outras espécies, mas reflete sobre o modo pelo qual os homens vivem juntos, não deixarão de contraditar a visão triunfante que sua terceira obra, a saber, $A$ evolução criadora, lança para a humanidade ao 
situá-la no ápice da história natural ${ }^{1}$. Atenhamo-nos, entretanto, à problemática da sociedade, da moral e da política.

Sob as lentes dessa filosofia, a ordem societária, que prima pela integração de seus membros num todo coeso, revela-se como a expressão de um movimento biologicamente fundado, o qual estabelece as disposições virtuais tanto para a humanização da espécie quanto para a constituição de uma ordem coletiva. É, pois, com um discurso que naturaliza a sociedade, que nos deparamos de imediato, ao iniciar a leitura de As Duas Fontes a moral e da religião. A ordem social é correlata dos organismos vivos. O enlace entre os indivíduos e a sociedade não difere substancialmente do vínculo entre células que se associam harmonicamente numa totalidade orgânica, as quais ' (...) subordinadas umas às outras numa sábia hierarquia (...) se vergam naturalmente, em vista de um bem maior do todo, a uma disciplina que poderá exigir o sacrifício da parte.' (BERGSON, 2009a, p.23) Uma metáfora, decerto. Sociedades humanas são constituídas por seres inteligentes e dotados de vontade livre, de sorte que a inserção social não se efetua fora dos aspectos psicológicos e morais. A analogia, entretanto, é poderosa e adquire todo o sentido se consideramos a regularidade das condutas sociais e o fato de que essas vontades, sempre aptas a agir de acordo com seu próprio arbítrio, findam por se homogeneizar e por engendrar um universo que se organiza de modo similar aos fenômenos naturais. Suas formas humanamente engendradas encontram seu fundamento primário na natureza viva e biológica.

Oriunda de um movimento criador que a ultrapassa, a sociedade, sustenta Bergson, atualiza-se em comportamentos ou em sistemas de hábitos que correspondem, guardadas as proporções, ao papel que as leis desempenham na ordem natural. Escreve ele: 'O hábito, servido pela inteligência e pela imaginação, introduz entre [os indivíduos] uma disciplina que imita de longe a unidade de um organismo de células anastomosadas, pela solidariedade que estabelece entre as individualidades distintas.' (BERGSON, 2009a, p.24) Não obstante, o enlace entre o conjunto das condutas

\footnotetext{
${ }^{1}$ Ao problematizar a notável inflexão que se instaura entre o terceiro e o último livro bergsonianos, $\mathrm{G}$. Waterlot, observa que o otimismo do filósofo com o destino e com o progresso do homem, prevalente em $A$ evolução criadora, terminou por ofuscar a mudança de perspectiva operada em sua última obra, momento em que a sua concepção acerca da natureza humana e do que se pode dela esperar nublase consideravelmente. Assim, ao deslocar seu interesse da inserção da espécie na história da vida e voltar-se para a história tecida por ela mesma e na qual ela se constrói socialmente, Bergson teria se defrontado com uma negatividade e com uma violência que se não chancelam em definitivo os seus caminhos, jamais serão superadas por completo. Pontua o comentador : '(...) quando Bergson quis considerar a espécie não mais na sua relação com as outras espécies, mas a espécie humana em sim ema e na forma sob a qual foi concretamente realizada, uma surpresa o esperava. É a surpresa que 0 reservava a vida social e o que ela revela da humanidade.' (WATERLOT, 2008, p.379)
} 
disciplinadas e a vida torna-se efetivo à medida que o conjunto dos hábitos se amalgamam e se integram, estabelecendo uma pressão que atua coercitivamente sobre os membros da sociedade mesmo que aqueles assim pressionados em nada se sintam constrangidos. Eis o todo da obrigação ou a moral social propriamente dita. Ou seja, para além do caráter individual e psicológico dos hábitos particulares, o conjunto orgânico deles todos ultrapassa as deliberações individuais e ratifica a unidade da ordem social, a qual por sua vez tinge cada um deles de um teor moral. Decorre daí que o sentimento de dever inerente a cada hábito imponha-se simultaneamente como força externa e interna. Instaura-se com isso uma fundamental diferença de natureza entre o todo das regras de conduta e cada um dos hábitos individuais. Estes psicológicos; aquele objetivo e social.

A conformidade entre o eu social e o todo da obrigação delineia-se como a partitura mestra da vida individual, ancorada num consentimento espontâneo, uma vez que a vida predispõe os indivíduos à obediência, aos hábitos. Contudo, a inteligência tende a antagonizar com os interesses do todo; sua prioridade parece ser a ação em prol de seus interesses; ela sabe que entre o Eu e os outros - ou a sociedade - não há fusão, mas clivagem. A possibilidade de priorizar seus desejos e paixões em detrimento do coletivo brilha no seu céu particular do indivíduo e a propensão natural à sociabilidade revela-se concomitante à da insociabilidade. O filósofo concede que, a despeito de nossas tendências ao hábito e à adesão ao todo da obrigação, a obediência ao dever nem sempre se dá no campo da facilidade, uma vez que ela é estremecida pelo assédio do egoísmo. Daí que a sujeição ao todo da obrigação exija, por vezes, um esforço contra si mesmo, revestindo-se de um aspecto árduo e constrangedor.

No momento em que os indivíduos aptos à escolha se recusam a desempenhar as condutas a eles impostas pela educação, mas consumadas de fato por suas disposições naturais, diferentes mecanismos coercitivos se fazem sentir e o obrigam ao ajuste. A liberdade inerente ao pensamento inteligente vê-se, pois, coibida por uma pressão que age para diluir os intentos de esquiva ante as exigências de regularidade e coesão, impondo a ela a tônica da necessidade. Daí a equivalência possível entre a conduta do indivíduo inserto na ordem social e a de uma célula no organismo que adquirisse um dia anseios de autonomia, ambos seriam capturados pela necessidade de coadunar-se ao todo. Imagem do autor, claro está. Sem dúvida, para dar voz a esse todo e conter os ímpetos apaixonados, o indivíduo deve agir sobre si mesmo, recorrendo aos cânones da razoabilidade. Isso não significa, que essa ação emane de logicidades quaisquer. Com efeito, a contenção das paixões jamais encontraria na razão ou na lógica sua autora privilegiada: 
Nunca, nas horas de tentação, sacrificaríamos à simples necessidade de coerência lógica o nosso interesse, a nossa paixão, a nossa vaidade. Porque a razão intervém com efeito como reguladora, num ser razoável, a fim de assegurar a coerência entre regras ou máximas, obrigatórias, a filosofia pode ver nela um princípio de obrigação (BERGSON, 2009a, p.34).

Vemos pois que à lógica cabe a sistematização e a organização dos interditos, jamais a sua produção. Se a resistência ao clamor passional se consuma e culmina na renúncia às disposições moralmente ilegítimas, é porque uma força que nos ultrapassa e que restabelece a eficácia dos valores ético-morais intervém, a saber, o todo da obrigação.

Nesse sentido, contemporizando com Bergson, podemos conceder que a mesma razão que resiste à pressão social - e moral - , numa contra atividade, viabilizará a interdição de suas propensões dissolventes. Mas sua atuação restringe-se a expressar o todo da obrigação, que se atualiza em seu discurso enquanto um correlato do instinto. É engenhoso o argumento: um imperativo moral será mais intensamente categórico à medida que se aproxime da natureza do instinto, ao qual o chamado da obrigação efetivamente se assemelha, uma vez que advém e se impõe antes que o raciocínio lógico possa se processar. Assim, as obrigações advindas da ordem social são análogas a um fato biológico. Nos termos do autor ' $\mathrm{E}$ o hábito mais poderoso, aquele cuja força é feita de todas as forças acumuladas de todos os hábitos sociais elementares, é necessariamente o que melhor imite o instinto.' (BERGSON, 2009a, p.39).

Entre os homens, a abertura para o progresso indeterminado coexiste com tendências que naturalmente impelem à constituição das regras morais e de uma ordem internamente organizada. Mas a ação da vida antes de se manifestar como uma determinação, se atualiza na liberdade de escolha, de sorte que a forma que os hábitos e as condutas por ventura assumam está destinada à invenção e à produção histórica, ainda que o hábito de contrair hábitos nada tenha de histórico. Logo, se o todo da obrigação encontra correlato no instinto que rege a conduta das outras espécies, no homem, esse instinto, que permanece intrínseco à inteligência, será virtual, uma potência de atualização em formas e destinos inusitados, sujeitos à invenção humana.

Seria lícito sustentar que a abertura e a liberdade para a instauração das formas morais foi a estratégia encontrada pela vida para fecundar o mundo dos homens com a sua exigência de regularidade e coesão e para garantir a continuidade da espécie. Só um ser inteligente sente-se obrigado. Mas a sociedade e a moralidade que lhe é coextensiva são produzidas por uma força infraintelectual que emana da vida e antecede as deliberações da inteligência. Bergson o sublinha: 
Um ser não se sente obrigado se não for livre, e cada obrigação, particularmente considerada, implica liberdade. Mas é necessário que haja obrigações; e quanto mais descemos dessas obrigações particulares, que se encontram no topo, até ao todo da obrigação que se encontra na base, mais a obrigação nos aparece como a própria forma que a necessidade assume no domínio da vida quando exige, pare certos fins, a inteligência, a escolha e, por conseguinte, a liberdade (BERGSON, 2009a, p.39).

Sob esse registro, sem reduzir o homem ao biológico, o filósofo postula que a presença do natural no mundo humano não pode ser erradicada, sua atuação é indefectível. O texto, outra vez: 'Engana-se quem diz 'quando se expulsa o natural, este regressa a galope', porque o natural não se deixa expulsar. Está sempre presente.' (BERGSON, 2009ª , p.227).

Uma leitura que buscasse confinar essas teses bergsonianas a um estágio primordial da história humana seria refutada pelo autor com veemência. Sabemos que a idéia de progresso encontra acolhimento fecundo nesta filosofia, o que não ocorre sem graus significativos de subversão. De acordo com o filósofo, o avanço do elã vital no seu embate com a matéria, do qual resultam a criação das formas vivas na natureza e das formas diversas de organização no mundo humano, não está isento de fracassos, pontos estanques, retrocessos, entorpecimentos. Não obstante, como mencionávamos a princípio, sem que se pulverizem as chances de malogro e a multiplicidade de ritmos, há evolução entre as espécies naturais, há história e avanço civilizacional no mundo humano, ainda que não necessário ou sujeito a determinações.

No que tange ao mundo da cultura, menores índices de desenvolvimento implicam um número de regras reduzidas, maior quantidade de interdições e um quase automatismo na adesão aos imperativos sociais. Prevalecem, desse modo, condutas menos dissonantes em relação às pressões que emanam da totalidade social e o essencial da obrigação se apresenta com maior nitidez. São de fato as chamadas sociedades primitivas ou mais próximas da natureza que revelam com mais contundência a ação da vida na constituição da ordem social. Nas sociedades modernas e heterogêneas, flexibiliza-se a coesão, multiplicam-se as leis, incrementa-se o descompasso entre o indivíduo e o grupo. Notadamente, se o texto bergsoniano serve-se de uma linguagem que nos remete aos primórdios da antropologia evolucionista, o faz apenas para observar que as grandes diferenças que separam o civilizado e o primitivo apenas esmaecem a semelhança incontornável que os aproxima. O acúmulo de conhecimento e a amplitude dos hábitos adquiridos no decorrer da história pode tornar o universo do primeiro mais dinâmico e variegado. Mas algo de essencial e necessário, de primitivo, pois, que não se altera historicamente e que advém do próprio movimento vital - o todo da 
obrigação -, será preservado na conformação de toda e qualquer ordem societária. Bergson é incisivo: "o natural foi em grande parte recoberto pelo adquirido, mas persiste pouco menos que imutável, através dos séculos. (...) o natural mantém-se em bastante bom estado, extremamente vivo na sociedade mais civilizada" (BEGSON, 2009a, p.39)

Entre o primitivo e o civilizado, um elo quase direto, um só e mesmo homem, o dirá F. Worms (cf.WORMS, 2008, p.53). A identidade entre eles, no entanto, não se esgota na presença intemporal da obrigação. Muito mais fortemente, ela se assenta no fato de que tanto as sociedades mais próximas da natureza quanto aquelas que atingiram o mais alto grau civilizatório constituem uma ordem fechada e encontram seu fundamento numa ética bélica, As regras morais vigentes numa determinada ordem social se impõem como dever e se atêm a um papel instrumental. A moralidade social é circular e vai, no dizer de Leopoldo e Silva, '(...) do individual ao social e do social ao individual' (1994, p. 289). Isso significa que o todo da obrigação, sob o qual se inscrevem os interesses societários expressa tacitamente uma exigência que se endereça a um contingente específico cuja identidade fixa sua diferença e sua distância em relação àqueles que lhe são estranhos.

Atentemos a essas duas passagens de $A s$ duas fontes da moral e da religião:

(...) quando afirmamos que o dever de respeitar a vida e a propriedade de outrem é uma exigência fundamental da vida social, de que sociedade falamos? Para responder a essa pergunta, basta considerarmos o que se passa em tempos de guerra. O homicídio e a pilhagem, do mesmo modo que a perfídia, a fraude e a mentira não se tornam simplesmente lícitos: passam a ser meritórios.(BERGSON, 2009a, p.40)

A outra, no último capítulo deste mesmo livro:

A sociedade fechada é aquela cujos membros se mantêm entre si, indiferentes ao resto dos homens, sempre prontos a atacar ou a defenderem-se, em obediência a uma atitude de combate. Tal é a sociedade humana quando sai das mãos da natureza (BERGSON, 20091, p.223).

Essas diferentes momentos do texto explicitam primeiramente que a preservação da ordem através da disciplina incute nos indivíduos os elementos necessários para uma coexistência harmônica entre os iguais, restringido a eles o alcance dos valores éticos. Para além de suas fronteiras, esses valores não se relativizam, antes se revertem. Atrocidades infindáveis cometidas contra esse outro são legitimadas e não suscitam perturbações morais de ordem alguma, porquanto para além dos contornos sociais, o humano não se configura e a moralidade traveste-se em imoralidade. A obrigação social se consolida, pois, ancorada no ódio contra todos aqueles que acenam com um distinto modus 
vivendi. Basta refletir acerca da naturalidade e facilidade com que nos ligamos afetivamente àqueles que nos são próximos, que falam a nossa língua e aos quais estamos unidos por vínculos emocionais e de parentesco, pondera Bergson. Aqui, inclusive, bastante próximo de Freud, para quem o nosso amor é precioso demais para ser destinado a quem não é igual a nós, ao passo que amar a humanidade implica uma difícil aprendizagem, um desvio do movimento afetivo e espontâneo que nos liga aos nossos semelhantes (cf. FREUD, 2010, p.13-123).

Em segundo lugar, as passagens mencionadas mostram que a disciplina com que nos conformamos a uma ordem fechada fomenta uma tendência belicista em relação àquele que por sua presença atesta a potencial fissura da unidade identitária, Revela-se assim a segunda terrível ameaça à conservação da ordem social: para além do egoísmo, a diferença. O filósofo vem ao nosso encontro: 'Quem não vê que a coesão social se deve, em grande parte, à necessidade de uma sociedade se defender contra outras, e que começa por ser contra todos os outros homens, que se ama os homens com os quais se vive?' (BERGSON, 2009, p.42) Intrínseca a toda e qualquer coletividade, a obrigação social em sua natureza de instinto virtual não consiste apenas na tendência a obedecer ou a aderir a condutas regulares, mais profundamente ela se traduz numa recusa violenta de toda alteridade, e se desnuda como um instinto de guerra. Em searas bersgonianas, o traço que perpassa toda cultura esteja ela nos primórdios ou nos píncaros do progresso civilizatório é o instinto de defesa do identitário. A intensa ferocidade ante tudo o que atualiza algum tipo de diferença chancela a natureza da vida comum enquanto clausura. Não é jamais a humanidade ampla e universal o norte de persecução da sociedade forjadas pela natureza.

Ademais, as sociedades fechadas tendem a produzir formas específicas de sistemas e regimes políticos, os quais serão igualmente fechados e ancorados na biologia. Em virtude da proximidade em relação às tendências estabelecidas pela natureza, as sociedades ditas primitivas constituem os cenários em que o exercício da liberdade tem alcance restrito e as formas de dominação apresentam uma estrutura mais inflexível. Mas elas nos desvelam o fato de que também nas instâncias políticas a vida esboça a estrutura elementar do comportamento humano. Ao voltar-se para essas sociedades, o filósofo destaca a ausência de dissidências em relação ao poder estabelecido, a presença de estruturas que fixam rigidamente o lugar dos dominantes e dos dominados. As formas de organização política que tendem a prevalecer nesse quadro remetem ao que tradicionalmente a ciência política classifica como sistemas oligárquicos e monárquicos, mesclando elementos de ambos: 
Um e outro regime confundem-se no estado rudimentar: é preciso um chefe, e não há comunidade sem privilegiados que tomem de empréstimo do chefe qualquer coisa do seu prestígio, (...). O comando é absoluto de um lado, a obediência é absoluta do outro. (BERGSON, 2009a, p. 232)

Não obstante, o filósofo alerta-nos de pronto: não se trata de apontar um determinismo natural que produziria homens destinados ao mando e outros à subordinação. É sutil o argumento bergsoniano.

Ao prefigurar a organização social na estrutura das espécies, a natureza as predispõe para relações de poder bastante precisas, fixando os indivíduos em condutas de comando ou de obediência. No mundo humano, no lugar de um instinto político estável, entra em cena uma singular e oscilante disposição. Submissão e dominação, conquanto se explicitem como tendências naturais, serão formas de condutas ligadas aos mecanismos psicológicos, tal como ocorre com a obrigação. Não haverá aqui fixidez. Em todo homem, insiste Bergson, constata-se a presença de um dimorfismo não físico, mas psíquico, o qual impede o enrijecimento do lugar ocupado pelo indivíduo nas relações de poder. Numa palavra, ninguém terá o destino natural e irremediavelmente chancelado pela condição de chefe ou súdito. Voltemos ao texto:

A verdade é que o dimorfismo faz, as mais das vezes, de cada um de nós, ao mesmo tempo, um chefe que tem o instinto de comandar e um súbdito que está pronto a obedecer, ainda que a segunda tendência prevaleça a ponto de se tornar a única aparente entre a maioria os homens (BERGSON, 2009a, p.232).

Essa dupla tendência - 'dois sistemas indivisíveis de qualidades' encontra seu correlato imagético na figura do caleidoscópio. Dependendo da vertente para a qual se volta esse instrumento, uma delas torna-se dominante, mas esta alternativa não se cristalizará numa única e irreversível conformação. O caleidoscópio estabiliza-se numa direção, mas o seu giro pode reconfigurar a opção anteriormente efetuada, tornando dominante a outra vertente, o que não necessariamente converge para resultados positivos. Na subjetividade de um indivíduo contido e introvertido, por exemplo, pode emergir um outro, surpreendente e antinômico ao temperamento prevalecente, e descortinar uma agressividade que culmina tanto em ações audaciosas e realizadoras, quanto em condutas violentas, típicas de um tirano ainda não desvelado. Bergson outra vez, espantosamente próximo de algumas análises de $\mathrm{H}$. Arendt:

Disso temos a visão clara em tempos de revolução. Cidadãos modestos, até então humildes e obedientes, despertam uma manhã com a pretensão de serem condutores de homens. O caleidoscópio, que se mantivera fixo, girou um grau e houve metamorfose. O resultado é algumas vezes bom: revelaram-se, assim, grandes homens de ação que ignoravam, eles mesmo, que o eram. Mas é em geral perturbador. Em seres honestos e mansos surge de súbito uma 
personalidade inferior, feroz, que é a de um chefe falhado. E aqui aparece um traço característico do animal político que é o homem (BERGSON, 2009a, p.233).

Como interpretar tais asserções? Não se trata, explicita o autor, de considerar que o gosto pelo mando ou pela liderança amalgamem-se de um modo inexorável a impulsos destrutivos ou a uma ferocidade incontida. Não é exatamente esse o ponto. A máxima aristotélica - o homem é um animal político - vem ratificar a presença de uma conduta prefigurada pela natureza, cuja gênese vincula-se à necessidade de sólida integração entre os membros de uma sociedade que se apóiam mutuamente. Posto que no mundo humano os indivíduos, ao exercerem sua vontade livre, tendem a liberar sua vocação egoística em detrimento dos interesses coletivos, a figuração das condutas de comando e de liderança, enquanto tendências forjadas pela vida, vem justamente ao encontro da urgência de conter o gosto pela liberdade e pelo mergulho nas paixões de toda ordem que assediam o homem e pairam como uma ameaça incessante ao tecido social. Somente uma energia intransigente poderia conter a sedutora possibilidade de priorizarmos e agirmos em prol de nossos desejos. Sob esse prisma, ao lado do hábito, do todo da obrigação, também a vocação para o comando com toda a violência nela implicada, presente tácita ou explicitamente em todos nós, revela-se uma estratégia vital afinada com os propósitos de preservação da espécie. O texto é contundente: '(...) é certo que a natureza, que massacra os indivíduos ao mesmo tempo que engendra as espécies, deve ter querido implacável, o chefe quando previu os chefes' (BERGSON, 2009a, p. 233). Desse modo, o animal político no homem, ainda que esteja também associado à questão da linguagem e ao uso da palavra, enlaça-se antes a uma propensão natural para a violência; comandar ou dirigir, ainda que possam se atualizar em estilos e modos altamente refinados, traduzem condutas ancoradas no desejo ou mesmo no prazer de subjugar outros homens, não necessariamente distintos de nós, submetendo-os inclusive pela violência se necessário for. Não percamos de vista que, em última instância, essa tendência atua como um dispositivo natural contra as tendências dissolventes que caracterizam os seres inteligentes. Subjaz às afirmações do autor a idéia, bastante freudiana, assinalemos, de que há em nós uma agressividade congênita. Mas, sob o registro do filósofo francês, tratase antes de uma violência a que a vida nos predispõe com o intuito conter a veemência dos impulsos egoísticos e de forçar a integração entre seres naturalmente dissidentes. Na história são muitos os exemplos de indivíduos que aprimoram e exercem essa vocação com requintes, mas o que essa reflexão destaca é que se os atos humanos e as escolhas deliberadas pela barbárie proliferam em toda a história civilizacional, eles não podem ser reduzidos à 
condição de excentricidades humanas. Inversamente, revelam-se como manifestações e atos prefigurados pela vida. Daí que a política, enquanto um instinto originário ou característica natural em nós se traduza potencialmente num desejo de subjugar ou de destruir o outro, mesmo que se trate de um semelhante. Desejo que, sob esse registro, encontra respaldo na própria vida.

Bergson procede, então, a uma espécie de fenomenologia dos afetos humanos ligados à condição de mando e de subordinação. Tendências que, adverte ele, são mais facilmente legíveis numa sociedade numerosa que tenha avançado na marcha civilizacional, mas cuja estrutura essencial permaneça ainda pouco eclipsada ou mais consetânea com as prefigurações naturais. Generaliza-se nestas sociedades um equívoco, a saber, a crença de que aqueles que ocupam as posições dirigentes são dotados de uma superioridade natural ou inata. Crença que é incrementada com um tipo de educação, disciplina e privilégios legitimamente praticados que cultivam e nutrem sistematicamente essa convicção, de modo que tanto os privilegiados quanto aqueles que a eles se submetem findam por tomar como inquestionável essa suposta pertinência a uma estirpe superior. Esta certeza da superioridade encontra, no outro extremo, afetos que a legitimam e a sustentam. $O$ instinto político para a dominação ou para ser dominado, ou, mais propriamente, o predomínio de um dos lados do caleidoscópio impede o reconhecimento de que os homens, quaisquer que seja o tempo ou a cultura em que vivam, compartilham a mesma natureza. Sob essa perspectiva, a idéia de que alguns são naturalmente propensos para o domínio ou para o comando revela seu caráter fictício. Afinal, de uma vez por todas, somos todos dimórficos.

A disposição para o embate e para a organização política, em última instância, mesmo depurada em suas formas com o progresso histórico, mesmo adornada por requintes e elegâncias do chamado mundo civilizado não deixa de ser em nós porta voz das intenções naturais. Por mais que nos civilizemos, por mais fecundo que seja o progresso humano, jamais nos evadimos das tendências que nos definem enquanto espécie ou da natureza inscrita em nós, a qual se traduz em vocação para a disciplina e para a exclusão de toda alteridade. A política revela-se, pois, um instinto que nos encerra e nos aprisiona a uma natureza violenta e sanguinária. O texto nos instrui: 'Monstruosidade, sem dúvida, mas pela qual a natureza é tão responsável como o homem. (...)'. E mais adiante, expresso com igual precisão: 'O instinto político original declara-se entre 'civilizados' para fazer explodir a civilização e deixar passar a natureza.' (BERGSON, 2009a, p.233).

Nesse quadro, o lugar do homem aproxima-se mais das espécies em geral do que ousaríamos sonhar. Correlato de pronto evocado pelo autor: 
Homens que se julgariam obrigados a proporcionar o castigo à ofensa, caso estivessem perante um culpado, passam diretamente a dar a morte ao inocente quando a política se faz ouvir. Do mesmo modo, as abelhas operárias apunhalam os machos quando consideram que a colméia deixa de precisar deles (BERGSON, 2009a, p.233).

Ao lume dessa análise, torna-se significativa que a política encontre sua razão de ser no assassinato. Além de naturalmente sociáveis, naturalmente etnocêntricos, somos naturalmente assassinos. O percurso aqui seguido deslinda-nos, o substrato elementar e essencial da sociedade humana, da moral e da política tal como figurada sob o registro do último Bergson. Munidos desse instrumental teórico, dois pontos nos conduzem ao término dessa reflexão.

O primeiro nos remete à problemática dos ideais modernos relativos às expectativas de progresso material e moral para todos os homens. A despeito de suas restrições, o homem circunscrito à sociedade fechada é ser singular. As outras espécies permanecem condenadas a repetir as formas de existência fixadas pelos instintos, ao passo que a abertura intrínseca à inteligência lança o homem nas sendas da invenção. $O$ mundo humano parece assim destinado ao aprimoramento sem fim; o progresso libertador parece ser o seu tom. Com efeito, o progresso das formas de administração da vida e de ação sobre a matéria está assegurado pela abertura e pela singularidade fabricadora da inteligência. Não obstante, circunscrito a uma ordem natural o ser inteligente é movido pelos instintos mais primários. Seu destino está selado dentro dos contornos do círculo naturalmente fixado - tal como o das outras espécies - e não ultrapassará os fins ligados à conservação e à guerra. A clausura - social, moral, política -, sempre obsequiosa da lógica identitária e comunitária, revela-se de pronto antinômica à constituição de representações que transbordem a clausura da ordem social; seu norte é sempre a ratificação de si mesma e seu lema é a recusa do outro. A renúncia à violência parece desprovida de sensatez. Aquele que viceja no ápice triunfal da história natural e também social, porquanto graças à sua existência, culmina na libertação da consciência ${ }^{2}$, ou seja, o maior sucesso da vida revela aqui a sua precariedade, como reconhece o filósofo em seus últimos escritos.

2 Como mencionado no início desse artigo, no final do capítulo III de $A$ evolução criadora, a compreensão bergsoniana do homem enquanto ser que perpetua indefinidamente o movimento vital explicita-se.. Na conferência A consciência e a vida, Bergson ratifica seu entusiasmo com o futuro humano assinalando que a perpetuação da atividade vital será operada também pelo conjunto da humanidade que, a despeito de seus conflitos, progride num crescente processo de integração e criação: ' As sociedades humanas são as únicas que mantêm o olhar fixado nos dois objetivos a atingir. Em luta consigo mesmas e em guerra umas com as outras, procuram visivelmente, pelo atrito e pelo choque, arredondar os ângulos, desgastar antagonismos, eliminar contradições, fazer as vontades 
O segundo ponto se traduz numa ponderação. É preciso observar que este cenário delineado pelo autor nos primeiros momentos do livro e retomados em seu término, quando a questão prática se impõe à reflexão, consiste num esforço de abstração que não é apenas teórico, mas, sobretudo, provisório. Se a reflexão bergsoniana se ativesse a esse quadro, que é abstrato, ela não teria ultrapassado o registro de uma sociobiologia, no qual o homem se reduz às instâncias mais elementares da existência e à condição de prisioneiro da natureza, o progresso humano se ateria à eficácia técnica, as associações entre as culturas seriam provisórias e mobilizadas por interesses circunstanciais, fadadas sempre a sucumbirem ante o advento da insociabilidade e da propensão bélica que nos constitui. $O$ que não se alcançaria jamais seria algum tipo de progresso moral ou político; jamais se consumaria o salto em direção à efetiva universalidade dos valores éticos ou à idéia de uma humanidade universal.

Não obstante, aquele que adentra este universo filosófico sabe que toda a obra bergsoniana postula a possibilidade de que a inteligência ultrapasse as pretensões da natureza. Será então necessário um esforço dilacerante, a partir do qual o homem opera a transgressão dos círculos, supera o divórcio com a criação e a fixação dos limites impostos pela materialidade e por sua própria conformação. O que assim se consuma é a difícil inserção no aberto, cujo pressuposto reside tanto num movimento da sensibilidade - a emoção criadora - quanto num amor que nada tem de natural porque plenamente desinteressado e que se direciona a toda a humanidade. Nesse viés, o pensar e o agir transmudam-se e autonomizam-se dos fins que regem as condutas socialmente estabelecidas, aquelas talhados pela lógica da conservação e da sobrevivência, o equilíbrio entre a multiplicidade dos egoísmos que compõem a ordem social já não esgota o sentido da existência humana. Esta verdadeira conversão ética se delineia na senda aberta pela intuição e pelo esforço criador por meio dos quais o homem funde-se com o dinamismo da vida e logra a superação das tendências que o conformam naturalmente. Eis o requisito para que se consumasse o salto para além de toda clausura, dos instintos virtuais, para além da natureza e da violência a ela coextensiva.

Em sua plenitude, afirmará o filósofo no desdobramento de sua última obra, essa dimensão seria alcançada apenas pelos indivíduos extraordinários, os místicos. Eles são os únicos que, com seu esforço individual e com seus atos criadores, logram superar a condição e os limites da espécie. Esse esforço, a despeito de seu caráter personalizado e solitário,

individuais inserirem-se na vontade social sem se deformar e as diferentes sociedades, por sua vez, entrarem (...) em uma sociedade mais ampla (...)!' (BERGSON, 2009b, p.26). 
repercute historicamente. Mais precisamente, com seu heroísmo inventivo e com seus atos exemplares, que inauguram uma inesperada conduta moral, esses homens contagiam o que há de mais profundo em outros homens e suscitam neles a impulsão do agir criador. Processo que pode inserir mudanças no fechado, as quais se inscreverão na moral e na política, ainda que não transmudem visceralmente a condição dos homens e não os emancipe de uma vez por todas de sua condição natural. A existência de todos eles transcorrerá ainda sob a égide da clausura, mas algo do aberto adentra as fronteiras do mundo humano, dinamizando-o. Os indivíduos assim tocados, tornam-se capazes de atos que já não se regem exclusivamente por um egoísmo circular entre o indivíduo e a sociedade, para retomarmos a expressão de Leopoldo e Silva, mas também por uma liberdade e por intenções voltadas para uma humanidade que transcende territórios e identidades.

Os fundamentos desse salto para o universal - concreto e jamais abstrato - na última obra bergsoniana não serão aqui problematizados. Mas importa assinalar que é com esta ruptura que se delineia o caminho para um homem desvencilhado do aprisionamento imposto pela biologia ${ }^{3}$. A difícil clivagem que conduz à abertura viabiliza que a sociedade, a moral e a política se tinjam de conotações radicalmente outras. Transmudação que, no dizer de Y. Kisukidi: '(...) toma a forma de uma emancipação da natureza, que deve se traduzir concretamente com o acontecimento de uma sociedade justa, igualitária, liberada de seus demônios imperialistas e xenófobos.'4.

Um mundo humano cabalmente emancipado, que traga a chancela da paz, não ultrapassará o registro da ficção. Bergson, contudo, não menospreza a imprevisibilidade que rege a história de seres inteligentes e dotados de vontade livre ${ }^{5}$. Certamente, homens exemplares, os verdadeiros heróis inventivos,

\footnotetext{
3 Para além dos temas que aqui nos mobilizaram, encontraremos ainda no último Bergson uma proposta de renovação do universalismo moral e político, assentada sobre a sua proposta absolutamente original de criação. Nessa direção ver KISUKIDI, 2012, p.245-266.

${ }^{4}$ KISUKIDI, 2012, p.247.

${ }^{5}$ Sob a perspectiva do filósofo, as escolhas humanas possuem um papel privilegiado na sucessão dos acontecimentos; a elas caberá decidir, inclusive, se a capacidade fabricadora do homem e as técnicas por ele inventadas devem aliar-se às intenções da natureza, ratificando ainda mais o exercício da barbárie entre os homens - 0 que parece ter se efetivado com a busca desenfreada do luxo e do prazer -, ou superá-las operando a convergência entre o desenvolvimento tecnológico e uma emancipação generalizada, tal como sonhado no limiar da modernidade. Eis o cenário em que se efetuaria 0 encontro entre a mística e a mecânica, como aventado por Bergson no último capítulo de seu último livro: ' $O$ misticismo está incontestavelmente na origem das grandes transformações morais. A humanidade parece, sem dúvida, mais do que nunca longe dele. (...) Entendeu-se durante muito tempo que industrialismo e maquinismo fariam a felicidade do gênero humano. Hoje, atribuir-se-lhes-iam facilmente os males de que sofremos. Nunca, ao que se diz, a humanidade teve tanta sede de prazer, de luxo e de riqueza. (...) As coisas nunca se fazem decerto por si sós. A humanidade não se modificará a não ser que queira modificar-se.' (BERGSON, 2009a, p.242).
} 
precursores de uma ética universal e libertadora, cujos atos reverberam e inebriam a humanidade através dos tempos, irromperam na história. Considerando-se que é no solo da indeterminação que se desdobra a vida humana - cujo progresso nada tem de previsível e só pode ser traçado com um olhar retrospectivo -, não há garantias de que essas existências venham a se repetir. Mas o fato de que elas já se concretizaram suscita a esperança numa sociedade outra, na qual talvez se minimizem as tendências violentas e homicidas, cujo espectro indelével e sempre à espreita permanece recôndito em cada um de nós.

As sendas trilhadas pelo autor, em sua reflexão sobre 'o que podemos esperar', são, sem dúvida, diversas daquelas sonhadas pelos iluministas e inscritas nos ideais modernos. Não encontraremos em suas reflexões ênfase alguma na idéia de progresso ou aprimoramento lastreado na crescente sofisticação da lógica ou de processos racionais. Os argumentos tecidos em $A s$ duas fontes da moral e da religião, no entanto, sugerem que a destinação humana aos círculos que contraditam o universal não é absoluta; esse destino não exclui os esforços em direção à abertura que adentra os círculos em que a existência humana se desenrola. Insistamos: a abertura é efêmera e não prepondera. A humanidade pode, no entanto, perseverar em seu desejo de transformação de si mesma. No dizer de Sitbon-Peillon: '(...) entre o fechado e o aberto há o 'entreaberto' por onde o dinâmico pode se infiltrar 'por contrabando' e humanizar o social, mesmo que a (...) abertura no fechado esteja destinada a se fechar em seguida. ${ }^{3}$. Esta inscrição do aberto na clausura do mundo social e, consequentemente, da moral e da política permite-nos considerar que o sonho de uma civilização mais autônoma e mais liberta das mãos da natureza não se evade por completo da reflexão bergsoniana. Ousaríamos mesmo sustentar que esse sonho cintila, ainda que incerto e esmaecido, no horizonte desta filosofia.

\section{Referências Bibliográficas}

BERGSON, Henry. A evolução Criadora, São Paulo: Martins Fontes, 2005. . O Pensamento e o Movente, São Paulo: Martins Fontes, 2006. . As duas fontes da moral e da religião, Coimbra: Almedina, 2009a.

${ }^{6}$ Brigitte Sitbon-Peillon. 'Bergson et le primitif: enter métaphysique et sociologie, In. Annales bergsoniennes I, p.187 
. A Energia Espiritual. São Paulo: Martins Fontes, 2009b.

DELEUZE, Gilles Bergsonismo, São Paulo: Editora 34, 1999.

FREUD, S. ‘O mal estar na civilização’, In: Obras completas, v.18. São Paulo: Cia das Letras, p.13-123, 2000.

GOUHIER, Henry. Bergson et le Christ des évangiles. Paris: A. Fayard, 1961.

KISUKIDI, Yala. "Création, universalisme et démocratie: la philosophie politique de Bergson dans Les Deux Sources de la morale et de la religion", Annales V. Paris: PUF, 2012.

KANT, I. A pazperpétua. Porto Alegre: LP\&M Editores, 2008.

LEOPOLDO E SILVA, Franklin. Bergson - Intuição e Discurso Filosófico São Paulo: Loyola, 1994.

STBON-PEILLON, Brigitte. "Bergson et le primitif : entre métaphysique et sociologie”. In WORMS, F. (Org). Annales Bergsoniennes I. Paris, PUF, 2001

WATERLOT, Ghislain. "Doutes sur l'bumanité: du 'succès unique et exceptionnel' de la vie dans L'Évolution créatrice au 'succès (...) si incomplet et si précaire' dans Les Deux Sources, "In: WORMS, F. (ed). Annales IV. Paris: PUF, 2008.

WORMS, Frédéric. "Le clos et l'ouvert dans Les Deux Sources de la morale et de la religion: une distinction qui change tout ". In: WATERLOO, G. (Org). Bergson et la religion. Paris: PUF, 2008.

. Bergson ou os dois sentidos da vida. São Paulo: Editora Unifesp, 2010. 